\title{
JAUNATVINIŲ SPUOGŲ DIAGNOSTIKOS BEI KOREGAVIMO GALIMYBIŲ KOSMETINĖMIS PRIEMONĖMIS IR PROCEDŪROMIS SĄSAJOS SU SUBJEKTYVIAI VERTINAMA SVEIKATA
}

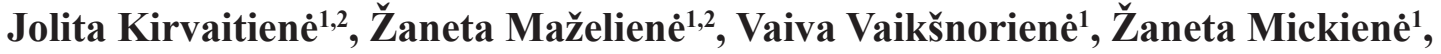 \\ Albina Vaičiulevičien $\dot{e}^{1}$ \\ ${ }^{1}$ Kauno kolegijos Sveikatos priežiūros fakultetas, \\ ${ }^{2}$ Lietuvos sveikatos mokslu universiteto Medicinos akademija
}

Raktažodžiai: jaunatviniai spuogai, cheminiai odos šveitikliai, Propionibacterium acnes, Staphylococcus aureus.

\section{Santrauka}

Paprastieji spuogai (acne vulgaris) - lètinè būklè, ženkliai paveikianti žmogaus gyvenimą, sąlygojanti socialinę elgseną, kelianti psichologines problemas, nuo jos nukenčia gyvenimo kokybė. Jaunatviniu spuogų problemų sprendimo būdų yra daug, pradedant kosmetikos priemonemis ir baigiant lazeriu. Vienas iš jaunatvinių spuogų odos būklès gerinimo metodų yra cheminiai šveitikliai.

Tyrimo tikslas - ịvertinti jaunatvinių spuogų diagnostikos ir koregavimo galimybių kosmetinèmis priemonėmis ir procedūromis sąsajas su subjektyviai vertinama klientų sveikata. Atlikto tyrimo duomenimis, nustatyta, kad klientai, kuriems retai kyla arba nesusiduria su inkštirų, odos riebalavimosi, pigmentinių dėmių problemomis, savo sveikatą vertina geriau. Aknė daugumai respondentų sukelia psichologinę ittampą, sunkumų laisvalaikiu / sportuojant, trukdo bendrauti su mylimaisiais, tokie klientai sveikatą vertina blogiau, nei tie, kuriems aknè tokio pobūdžio sunkumų nesukelia arba sukelia retai $(p<0,05)$. Besiskundžiantys akne ir aktyviai spendžiantys šią problemą gydytojo, kosmetologo konsultacijomis, aparatinèmis procedūromis bei specialiomis kosmetinėmis priemonemis, savo sveikatą vertina geriau.

Klientams atliktos trys odos šveitimo procedūros su vaisinėmis alfa hidroksi rūgštimis turejjo teigiamą efektą odos būklei. Analizuojant duomenis apie klientų odos būklę po atliktų procedūrų, nustatyta, kad daugiau nei ketvirtadaliu padidejo skaičius kli- entų, kuriems buvo diagnozuotas normalus hidratacijos (drègmès) lygis ir trečdaliu sumažèjo klientų su žemos hidratacijos (drègmès) lygiu bei 1,5 karto padidejjo skaičius klientų, kuriems buvo diagnozuotas normalus odos ph, lyginant po pirmosios ir trečiosios procedūros. Nustatyti klientų veido odos porų diametro pokyčiai: daugiau nei du kartus sumažèjo klientų skaičius, kuriems diagnozuotos labai atviros odos poros, lyginant po pirmosios ir trečiosios procedūros. Kosmetologo vizualinès diagnostikos metu stebimi odos papulių ir pustulių skaičiaus sumažejimas.

\section{Ivadas}

Paprastieji spuogai (acne vulgaris) - odos riebalų liaukos ir viršutinès plauko folikulo dalies uždegimas. Bendrinis šios odos ligos pavadinimas - aknè - dažniausiai apibrèžia spuoguotą, inkštiruotą odą, gali apimti ịvairias kūno vietas, kur gausu riebalinių liaukų, būna įvairių sunkumo formų, tai priklauso nuo sergančiojo imuninès sistemos, taikomo gydymo, odos priežiūros, naudojamų kosmetinių bei aparatinių priemonių, ir kitų veiksnių [1,2]. Nors paaugliai nuo šios ligos kenčia dažniausiai, neretai ji pasireiškia ir suaugusiems, sulaukusiems 25-40 metų amžiaus, tai vadinamoji vèlyvoji aknè. Epidemiologinių tyrimų duomenimis, išsivysčiusių šalių paauglių populiacijoje aknès paplitimas siekia 50-95 proc. (priklauso nuo odos pažeidimų vertinimo metodikos), o vidutinio sunkumo ar sunki aknè nustatoma $20-35$ proc. Aknès atsiradimą lemia keli patogeneziniai veiksniai: odos riebalinių liaukų padidejęs aktyvumas, folikulu hiperkeratozè, Propionibacterium acnes kolonizacija ir uždegiminè reakcija, prie kurios prisideda Staphylococcus aureus [3]. Paprastieji spuogai - lètinè būklè, ženkliai paveikianti žmogaus gyvenimą, sąlygojanti socialinę elgseną, kelianti psichologines problemas, nuo 
jos nukenčia gyvenimo kokybė [4,5]. Jaunatvinių spuogų problemu sprendimo būdų yra daug, pradedant kosmetikos priemonemis ir baigiant lazeriu. Vienas iš jaunatvinių spuogų odos būklès gerinimo metodų yra cheminiai šveitikliai. Atsižvelgiant į American Society of Plastic Surgeons tarpdisciplinini tyrimą cheminiai šveitikliai yra pripažinti kaip mažiausia invazinè kosmetinè procedūra. Teigiama, kad cheminiai šveitikliai niekada neišnyks dèl histologiškai pagrịsto naudingumo, sąnaudų, veiksmingumo, saugumo tinkamai juos naudojant. Cheminių šveitiklių panaudojimas yra gana platus. Jie yra veiksmingi naudojant vienus, atliekant kombinacijas, taip pat pasižymi įvairiu poveikiu jaunatviniams spuogams: padeda sumažinti jaunatvinių spuogų bėrimo elementus, atsluoksniuoja viršutinį odos sluoksnį, atveria užsikimšusias odos poras, sumažina hiperpigmentaciją, atsiradusią po uždegiminių bèrimo elementų [6-9].

Uždaviniai: diagnozuoti jaunatvinius spuogus, rezultatus pagrindžiant kosmetologine diagnostika bei mikrobiologiniu tyrimu; nustatyti jaunatvinių spuogų problemos sprendimo galimybes kosmetinèmis priemonemis bei procedūromis; įvertinti jaunatvinių spuogų koregavimo galimybių kosmetinėmis priemonemis ir procedūromis sąsajas su subjektyviai vertinama klientų sveikata.

Tyrimo tikslas: ịvertinti jaunatvinių spuogų diagnostikos bei koregavimo galimybių kosmetinèmis priemonèmis ir procedūromis sąsajas su subjektyviai vertinama klientų sveikata.

\section{Kontingentas ir tyrimo metodai}

Tiriamają grupę sudare 147 Kauno kolegijos I ir III kurso studentai, besiskundžiantys jaunatviniais spuogais. Kiekvieną tyrimo dalyvị konsultavo gydytojas kosmetologas, pokalbio metu buvo surinkta kosmetologinè anamnezè bei pildomas parengtas adaptuotas gyvenimo kokybès klausimynas. Iš 147 apklausoje dalyvavusių asmenų pagal parengtus indikatorinius atrankos kriterijus: tiriamujų amžius 14 - 40 metų; veido srities lengva ar vidutinio sunkumo aknè (uždari, atviri komedonai, papulès, pustulès, mazgeliai) ir jos sąlygoti liekamieji reiškiniai (postakniniai randeliai, použdegiminė hiperpigmentacija); pasirašyta asmens informavimo ir informuoto asmens sutikimo forma; buvo atrinkti 52 asmenys, kurie sutiko dalyvauti tolimesneje tyrimo eigoje. I tolimesnį tyrimą neįtraukti asmenys, kurie turèjo nors vieną iš išvardintų kriterijų: nèštumas, žindymas; veido srityje aktyvios virusinès, bakterinès ar grybelinès infekcijos požymiai; veido srityje anksčiau nei prieš 6 mèn. atlikta operacija, lazerio, dermabrazijos, krioterapijos ar kitos procedūros, galejjusios pažeisti ar pakeisti odos struktūrą; imunosupresinès ar onkologinès ligos; alergija ir/ arba žinomas padidèjęs jautrumas ar kitas žinomas ir/arba galimas nesuderinamumas su viena ar keliomis preparato sudètinèmis dalimis; sistemiškai vartojamas izotretinoinas ar vietiškai naudojami retinoidai; keloidų ir/ar hipertrofinių randų vystymosi šeimoje istorija; použdegiminès hiperpigmentacijos šeimoje vystymosi istorija.

Atrankos kriterijus atitinkantiems 52 klientams, besiskundžiantiems jaunatviniais spuogais, kas 10 dienų buvo atliktos trys odos šveitimo procedūros su vaisinèmis alfa hidroksi rūgštimis $(20$ - 35 proc., ph 1,6 - 1,3) pagal Neostratos metodiką. Šveitiklių stiprumas parenkamas pagal odos būklę. Skirtingų koncentracijų rūgštys buvo renkamos atsižvelgiant ị tiriamojo odos reakciją ị rūgštį. Procedūros atliktos laikantis gamintojo pateiktu procedūros protokolu. Tyrimo metu jaunuoliai nenaudojo kosmetiniu priemonių, ị kurių sudètį įeina cheminès rūgštys, retinoidų, antikoaguliantų, taip pat neatliko kosmetinių procedūrų, galinčių pakeisti odos struktūrą, kad būtų nustatytas tikslus cheminių šveitikliu poveikis, sprendžiant I ir II stadijos jaunatvinių spuogų problemas. Prieš kiekvieną procedūrą buvo atliekamas odos būklès vertinimas. Odos būklè buvo vertinama pigmentacijos ir odos bérimo elementų vertinimu apžiūros būdu, atsižvelgiant ì pigmentacijos lokalizaciją, kuriose veido srityse yra daugiau išryškejjusi, taip pat atsižvelgiama i pigmentacijos pakitimus (antrinè pigmentacija, atsiradusi po jaunatvinių spuogų). Vertinant odos bérimų elementų skaičių buvo atsižvelgiama i komedonų tipą - uždari ar atviri, jų lokalizaciją, uždegiminius bèrimo elementus - lokalizaciją, odos bẻrimo elementų skaičių. Prieš kiekvieną procedūrą objektyvių odos parametrų - odos riebumo, porų dydžio, odos $\mathrm{pH}$, melanino, drégmès kiekių, elastingumo vertinimas atliktas diagnostiniu „Soft plius“ aparatu. Jis buvo atliekamas vadovaujantis diagnostinio aparato naudojimosi protokolu. Odos būklès parametrai buvo vertinami pasirinkus programą „Face + + “. Drègmés kiekis odoje matuojamas šiose veido srityse: kakta, abu skruostai, smakras, odos riebumas matuojamas - kaktos ir dešiniojo skruosto srityje, odos $\mathrm{pH}$ - nosies sparnelių - skruosto srityje, odos elastingumas - „žąsies kojelių“ srityje, odos porų dydis matuojamas panaudojant diagnostinio aparato mikrokamerą ir apibrežiant porą, tokiu būdu diagnostinis aparatas apskaičiuoja poros diametrą.

Siekiant nustatyti aknès etiologiją iš 52 Kauno kolegijos Kosmetologijos katedroje aknès gydomosioms procedūroms apsilankiusių klientu 23 buvo paimta tiriamoji medžiaga ir atliktas mikrobiologinis tyrimas, išskiriant ir identifikuojant Propionibacterium acnes ir Staphylococcus aureus [10]. Tiriamoji medžiaga (pūlių mėginys) iš gilesnio spuogo sluoksnio paimta tamponu i SSI transportinę terpę. Pūliai bakteriologiškai ištirti Nacionalinèje visuome- 
nės sveikatos priežiūros laboratorijoje Kaune ir LSMU Mikrobiologijos katedroje. Tiriamoji medžiaga Nacionalinejje visuomenès sveikatos priežiūros laboratorijoje, anaerobinių Propionibacterium acnes bakterijų kultivavimui, pasèti i mitybinę Schaedler agaro terpę anaerobinių bakterijų, kurios sudetyje yra 5 proc. kraujo. Sporų nesudarančios Propionibacterium acnes bakterijos anaerobinėse kultivavimo sąlygose išaugo po 48 valandų inkubacijos $37^{\circ} \mathrm{C}$ temperatūroje. Propionibacterium acnes bakterijos augo didelèmis baltomis ar gelsvomis kolonijomis, su $\beta$ hemolizès zona. Mikroskopuojant Gramo būdu nudažytus kolonijų tepinèlius rastos gramteigiamosios lazdelès. Propionibacterium acnes identifikuotos biocheminiais testais (Anaerotest 23 Lachema ir ApiA Bio-Mérieux).

Staphylococcus aureus iš tiriamosos medžiagos (spuogo pūlių) išskirti ir identifikuoti LSMU MA Mikrobiologijos katedroje. Tiriamoji medžiaga pasèta ị manito druskos agarą („LAB M“ Mannitol salt agar) ir kultivuota 24 val. $35-37^{\circ} \mathrm{C}$ temperatūroje. Staphylococcus aureus skaido manitą ir jų kolonijos nusidažo geltona spalva, augant kraujo agare Staphylococcus aureus būdinga $\beta$ hemolizè. Mikroskopuojant gramo būdu dažytus tepinèlius matomi gramteigiamieji kokai. Staphylococcus aureus identifikuotas plazmokoaguliazès (Coagulase Plasma, Rabbit with EDTA, BBL) ir DNR-azès (LAB M DNase agar) testais.

Statistinè duomenų analizè atlikta naudojant SPSS programos paketą (versija SPSS 17.0). Hipotezès apie požymių ryši tikrintos taikant chi kvadrato $\left(\chi^{2}\right)$ kriterijų. Minimalus reikšmingumo lygmuo - 0,05 .

\section{Rezultatai}

Tyrimo duomenimis, nustatyta, kad klientai, kuriems retai kyla arba nesusiduria su inkštirų, odos riebalavimosi, pigmentinių dėmių problemomis savo sveikatą vertina geriau. Respondentai, kuriems inkštirų bei pūlingų inkštirų problema kyla kartą per savaitę du kartus dažniau teigia jog jų sveikata patenkinama/bloga, nei gera/ vidutiniška (atitinkamai inkštiru - 68,3 proc. ir 31,7 proc. bei pūlingų inkštiru - 44,9 proc. ir 29,0 proc., $\mathrm{p}<0,05)$. Daugiau nei trečdalis klientų, kuriems susidaro pigmentinès dèmès, kartą per mènesį teigia, jog jų sveikata patenkinama/bloga. 1 lentelèje pateiktas klientų subjektyvaus sveikatos vertinimo dažnis atsižvelgiant $i \mathfrak{\text { aknès formas. }}$

Tyrimo analizès duomenimis, kurie pateikti 2 lentelèje, nustatyta, kad aknė daugumai respondentų sukelia psichologines problemas, sunkumų laisvalaikiu/sportujant, trukdo bendrauti su mylimaisiais, tokie klientai sveikatą vertina blogiau nei tie, kuriems aknė tokio pobūdžio sunkumų nesukelia arba sukelia retai. Tik dešimtadalis respondentų, kuriems kartą per savaitę dèl aknès problemos kyla sunkumų bendraujant su mylimaisiais bei jie jaučia psichologinę itampą, teigia, jog jų sveikata yra gera / vidutiniška, visi kiti teigia - patenkinama / bloga (atitinkamai 8,3 proc. ir 91,7 proc., $p<0,05$ ), o puikiai/ labai gerai vertinusių sveikatą klientų nebuvo. Panašios tendencijos stebimos ir su patiriamais sunkumais laisvalaikiu / sportuojant. Respondentai, kuriems kartą per savaitę dèl aknès problemos kyla sunkumų laisvalaikiu / sportuojant, keturis kartus dažniau teigia, jog jų sveikata patenkinama/bloga, nei gera / viduti-

1 lentelè. Klientų subjektyvaus sveikatos vertinimo dažnis (proc.) atsižvelgiant $i \mathfrak{\text { aknès formas }}$

\begin{tabular}{|c|c|c|c|c|c|c|}
\hline \multirow{2}{*}{ Požymis } & \multirow{2}{*}{$\begin{array}{c}\text { Subjektyvus } \\
\text { sveikatos } \\
\text { vertinimas }\end{array}$} & \multicolumn{4}{|c|}{$\begin{array}{c}\text { Dažnis (proc.) } \\
\text { (N=147) }\end{array}$} & \multirow{2}{*}{$\begin{array}{l}\text { Reikšmingumo } \\
\text { lygmuo }\end{array}$} \\
\hline & & $\begin{array}{l}\text { Netenka } \\
\text { susidurti }\end{array}$ & $\begin{array}{l}\text { Dažna1/ } \\
\text { maždaug } \\
\text { kartą per } \\
\text { savaitę }\end{array}$ & $\begin{array}{c}\text { Maždaug } \\
\text { kartą per } \\
\text { mėnesi }\end{array}$ & $\begin{array}{l}\text { Maždaug } \\
\text { kartą per } \\
\text { pusę metų/ } \\
\text { rečiau }\end{array}$ & \\
\hline \multirow[t]{3}{*}{ Inkštirai } & Puiki/labai gera & 91,7 & 0 & 13,0 & 30,4 & \multirow{3}{*}{$\begin{array}{c}\chi^{2}=18,162 \\
11 \mathrm{~s}=2 \\
\mathrm{p}=0,001(\mathrm{sp})\end{array}$} \\
\hline & Gera / vidutiniška & 8,3 & 31,7 & 21,7 & 51,1 & \\
\hline & Patenkinama / bloga & 0 & 68,3 & 65,3 & 18,5 & \\
\hline \multirow{3}{*}{$\begin{array}{l}\text { Pūlingi } \\
\text { inkštirai }\end{array}$} & Puiki/labai gera & 100,0 & 26,5 & 37,8 & 0 & \multirow{3}{*}{$\begin{array}{c}\chi^{2}=32,959 \\
11 \mathrm{~s}=4 \\
\mathrm{p}=0,001(\mathrm{sp})\end{array}$} \\
\hline & Gera / vidutiniška & 0 & 29,0 & 59,5 & 0 & \\
\hline & Patenkinama /bloga & 0 & 44,9 & 2,7 & 0 & \\
\hline \multirow{3}{*}{$\begin{array}{l}\text { Odos } \\
\text { riebalavimasis }\end{array}$} & Puiki/labai gera & 91,7 & 28,3 & 36,1 & 0 & \multirow{3}{*}{$\begin{array}{c}\chi^{2}=26,803 \\
11 s=4 \\
\mathrm{p}=0,001(\mathrm{sp})\end{array}$} \\
\hline & Gera / vidutiniška & 8,3 & 47,5 & 61,1 & 0 & \\
\hline & Patenkinama / bloga & 0 & 24,2 & 2,8 & 0 & \\
\hline \multirow{3}{*}{$\begin{array}{l}\text { Pigmentiès } \\
\text { dèmés }\end{array}$} & Puiki/labai gera & 46,9 & 0 & 22,6 & 8,1 & \multirow{3}{*}{$\begin{array}{c}\chi^{2}=35,274 \\
11 \mathrm{~s}=4 \\
\mathrm{p}=0,001(\mathrm{sp})\end{array}$} \\
\hline & Gera / vidutiniška & 28,6 & 0 & 37,7 & 89,2 & \\
\hline & Patenkinama /bloga & 24,5 & 0 & 39,7 & 2,7 & \\
\hline
\end{tabular}

$\chi^{2}$-chi-kvadrato kriterijus; lls - laisvès laipsniu skaičius; p - reikšmingumo lygmuo; sp - statistiškai patikima 
2 lentelė. Klientų dẻl aknès keliamų problemų patiriančių sunkumų sąsajos su subjektyviu sveikatos vertinimu

\begin{tabular}{|c|c|c|c|c|c|c|}
\hline \multirow[b]{2}{*}{ Požymis } & \multirow[b]{2}{*}{$\begin{array}{c}\text { Subjektyvus } \\
\text { sveikatos } \\
\text { vertinimas }\end{array}$} & \multicolumn{4}{|c|}{$\begin{array}{c}\text { Dažnis (proc.) } \\
(\mathrm{N}=147)\end{array}$} & \multirow[b]{2}{*}{$\begin{array}{c}\text { Reikšmin- } \\
\text { gumo } \\
\text { lygmuo }\end{array}$} \\
\hline & & $\begin{array}{r}\text { Netenka } \\
\text { susidurti }\end{array}$ & $\begin{array}{c}\text { Dažnai/ } \\
\text { maždaug } \\
\text { kartą per } \\
\text { savaitę }\end{array}$ & $\begin{array}{c}\text { Maždaug } \\
\text { kartą per } \\
\text { mėnesị }\end{array}$ & $\begin{array}{c}\text { Maždaug } \\
\text { kartą per } \\
\text { pusę metų/ } \\
\text { rečiau }\end{array}$ & \\
\hline \multirow{3}{*}{$\begin{array}{c}\text { Sunkumai } \\
\text { bendraujant su } \\
\text { mylimaisiais }\end{array}$} & Puiki/labai gera & 38,1 & 0 & 34,0 & 23,1 & \multirow{3}{*}{$\begin{array}{c}\chi^{2}=33,781 \\
11 \mathrm{~s}=2 \\
\mathrm{p}=0,001 \\
(\mathrm{sp})\end{array}$} \\
\hline & Gera / vidutiniška & 59,8 & 8,3 & 4,0 & 76,9 & \\
\hline & Patenkinama / bloga & 2,1 & 91,7 & 62,0 & 0 & \\
\hline \multirow{3}{*}{$\begin{array}{l}\text { Psichologinè } \\
\text { ịtampa }\end{array}$} & Puiki / labai gera & 38,1 & 0 & 22,0 & 23,1 & \multirow{3}{*}{$\begin{array}{c}\chi^{2}=26,76 \\
1 l s=2 \\
p=0,001 \\
(s p)\end{array}$} \\
\hline & Gera / vidutiniška & 59,8 & 8,3 & 24,0 & 76,9 & \\
\hline & Patenkinama / bloga & 2,1 & 91,7 & 54,0 & 0 & \\
\hline \multirow{3}{*}{$\begin{array}{c}\text { Sunkumai } \\
\text { laisvalaikiu/ } \\
\text { sportuojant }\end{array}$} & Puiki / labai gera & 34,1 & 0 & 50,4 & 44 & \multirow{3}{*}{$\begin{array}{c}\chi^{2}=19,136 \\
l l s=2 \\
p=0,001 \\
(s p)\end{array}$} \\
\hline & Gera / vidutiniška & 63,5 & 18,3 & 1,6 & 53,0 & \\
\hline & Patenkinama / bloga & 2,4 & 81,7 & 48,0 & 3,0 & \\
\hline
\end{tabular}

$\chi^{2}$ - chi-kvadrato kriterijus; lls - laisvés laipsniu skaičius; $p$ - reikšmingumo lygmuo; sp - statistǐ̌kai patikima

3 lentelè. Klientų subjektyvaus sveikatos vertinimo dažnis (proc.) atsižvelgiant ị naudojamas priemones aknès keliamoms problemoms spręsti.

\begin{tabular}{|c|c|c|c|c|c|c|}
\hline \multirow{2}{*}{$\begin{array}{l}\text { Naudojamos } \\
\text { priemonès }\end{array}$} & \multirow{2}{*}{$\begin{array}{l}\text { Subjektyvus } \\
\text { sveikatos } \\
\text { vertinimas }\end{array}$} & \multicolumn{4}{|c|}{$\begin{array}{c}\text { Dažnis (proc.) } \\
(\mathrm{N}=147)\end{array}$} & \multirow{2}{*}{$\begin{array}{c}\text { Reikšmingumo } \\
\text { lygmuo }\end{array}$} \\
\hline & & $\begin{array}{l}\text { Netenka } \\
\text { susidurti }\end{array}$ & $\begin{array}{l}\text { Dažnai/ } \\
\text { maždaug } \\
\text { kartą per } \\
\text { savaitę }\end{array}$ & $\begin{array}{l}\text { Maždaug } \\
\text { kartą per } \\
\text { męnesị }\end{array}$ & $\begin{array}{c}\text { Maždaug } \\
\text { kartą per pusę } \\
\text { metu/ rečiau }\end{array}$ & \\
\hline \multirow{3}{*}{$\begin{array}{l}\text { Mechaninis } \\
\text { veido } \\
\text { valymas }\end{array}$} & Puiki/labai gera & 39,7 & 45,9 & 65,4 & 22,0 & \multirow{3}{*}{$\begin{array}{c}\chi^{2}=7,489 \\
1 l s=2 \\
p=0,001(s p)\end{array}$} \\
\hline & Gera / vidutiniška & 41,3 & 32,3 & 26,9 & 56,1 & \\
\hline & Patenkinama / bloga & 19,0 & 21,8 & 7,7 & 21,9 & \\
\hline \multirow{3}{*}{$\begin{array}{l}\text { Aparatinès } \\
\text { procedūros }\end{array}$} & Puiki / labai gera & 91,7 & 28,6 & 35,1 & 0 & \multirow{3}{*}{$\begin{array}{c}\chi^{2}=26,457 \\
11 s=4 \\
p=0,001(s p)\end{array}$} \\
\hline & Gera / vidutiniška & 8,3 & 45,9 & 64,9 & 0 & \\
\hline & Patenkinama / bloga & 0 & 25,5 & 0 & 0 & \\
\hline \multirow{3}{*}{$\begin{array}{l}\text { Riebios odos } \\
\text { procedūros }\end{array}$} & Puiki / labai gera & 39,8 & 25,0 & 0 & 30,0 & \multirow{3}{*}{$\begin{array}{c}\chi^{2}=23,361 \\
11 s=4 \\
p=0,001(s p)\end{array}$} \\
\hline & Gera / vidutiniška & 40,9 & 66,7 & 45,5 & 57,5 & \\
\hline & Patenkinama / bloga & 13,0 & 8,3 & 55,4 & 12,5 & \\
\hline \multirow{3}{*}{$\begin{array}{c}\text { Šveitikliai su } \\
\text { alfahidroksi } \\
\text { rūgštimis }\end{array}$} & Puiki / labai gera & 34,3 & 62,3 & 0 & 24,6 & \multirow{3}{*}{$\begin{array}{c}\chi^{2}=17,070 \\
11 s=2 \\
p=0,001(s p)\end{array}$} \\
\hline & Gera / vidutiniška & 49,3 & 37,7 & 0 & 54,1 & \\
\hline & Patenkinama / bloga & 16,4 & 0 & 0 & 21,3 & \\
\hline \multirow{3}{*}{$\begin{array}{c}\text { Specialios } \\
\text { kosmetikos } \\
\text { naudojimas }\end{array}$} & Puiki / labai gera & 30,1 & 58,3 & 0 & 42,1 & \multirow{3}{*}{$\begin{array}{c}\chi^{2}=30,792 \\
1 l s=4 \\
p=0,001(s p)\end{array}$} \\
\hline & Gera / vidutiniška & 38,4 & 37,5 & 91,7 & 57,9 & \\
\hline & Patenkinama / bloga & 31,5 & 4,2 & 8,3 & 0 & \\
\hline
\end{tabular}

$\chi^{2}$ - chi - kvadrato kriterijus; lls - laisvés laipsniu skaičius; p - reikšmingumo lygmuo; sp - statistiškai patikima sižvelgiant ì naudojamas priemones aknès keliamoms problemoms spręsti. Aštuonis kartus dažniau klientai, kuriems kartą per mènesi atliekamas veido valymas, teigia, jog jų sveikata puiki / labai gera, lyginant su klientais, teigiančiais, kad jų sveikata patenkinama/bloga (atitinkamai 62,3 proc. bei 7,7 proc., $\mathrm{p}<0,05$ ).

Beveik trečdalis respondentų, kuriems kartą per savaitę dèl aknès problemų buvo atliekamos aparatinès procedūros, savo sveikatą vertino kaip puikią / labai gerą, daugiau nei du ketvirtadaliai vertino kaip gerą/ vidutinišką. Panašios sveikatos vertinimo tendencijos stebimos ir klientų, kuriems kartą per savaitę atliekamos riebios odos procedūros: tris kartus dažniau tokie klientai, teigia, jog jų sveikata puiki / labai gera, lyginant su klientais, teigiančiais, kad jụ sveikata patenkinama / bloga (atitinkamai 25,0 proc. bei 8,3 proc., $\mathrm{p}<0,05)$. Respondentai, kuriems kartą per savaitę dèl aknès problemų atliekamų kosmetinių procedūrų metu buvo naudojami šveitikliai su alfahidroksi rūgštimis, savo sveikatą vertino teigiamai: daugiau nei du trečdaliai kaip - puikią/ labai gerą, daugiau trečdalis vertino kaip gera/ vidutinišką (atitinkamai 62,3 proc. bei 37,7 proc., $\mathrm{p}<0,05)$. Taip pat klientai, kurie nuolatos vartoja specialią kosmetiką, sveikatą vertina teigiamai: beveik du trečdaliai kaip niška (atitinkamai 81,7 proc. ir 18,3 proc., $\mathrm{p}<0,05$ ).

Tyrimo duomenimis, nustatyta, kad klientai, besiskundžiantys akne ir aktyviai spendžiantys šią problemą gydytojo, kosmetologo konsultacijomis, aparatinemis procedūromis bei specialiomis kosmetinèmis priemonès, savo sveikatą vertina geriau. 3 lentelëje pateikti duomenys apie klientų subjektyvaus sveikatos vertinimo dažnị (proc.) at-
- puikią / labai gerą, daugiau kaip trečdalis vertino kaip gerą / vidutinišką (atitinkamai 58,3 proc. bei 37,5 proc., $\mathrm{p}<0,05)$.

Klientams atliktos trys odos šveitimo procedūros su vaisinèmis alfa hidroksi rūgštimis turèjo teigiamą efektą odos būklei. Pirmame paveiksle pateikti klientų veido odos hidratacijos (drègmès) lygio pokyčiai (proc.) "Soft plius" 


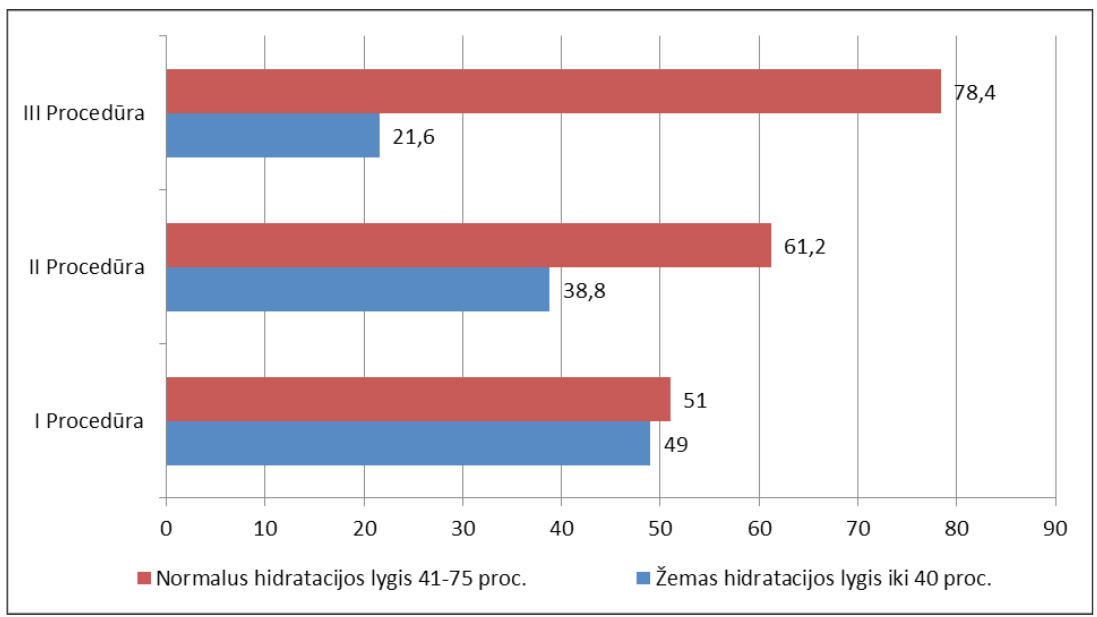

1 pav. Klientų veido odos hidratacijos (drègmès) lygio pokyčiai (proc.) Soft plius diagnostinio aparato duomenimis

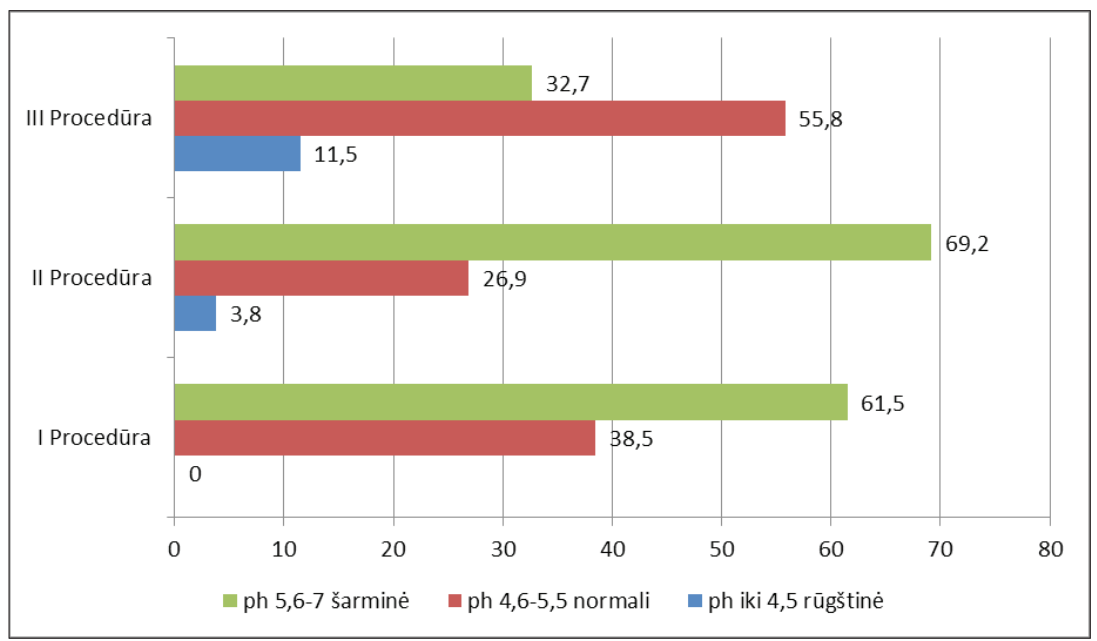

2 pav. Klientų veido odos ph pokyčiai (proc.) Soft plius diagnostinio aparato duomenimis

4 lentelè. Iš spuogų pūlių išaugintos bakterijos

\begin{tabular}{|l|l|c|c|c|}
\hline \multirow{2}{*}{ EN } & \multicolumn{1}{|c|}{ Bakterijos } & \multicolumn{3}{|c|}{ Padermių skaičius } \\
\cline { 3 - 5 } & $\begin{array}{c}\text { Ǐs viso } \\
\text { tirta }\end{array}$ & $\begin{array}{c}\text { Ǐskirta } \\
\text { padermių }\end{array}$ & $\begin{array}{c}\text { Neišskirta } \\
\text { padermių }\end{array}$ \\
\hline 1. & $\begin{array}{l}\text { Propionibacterium } \\
\text { acnes }\end{array}$ & $\begin{array}{c}100 \text { proc. } \\
(\mathrm{n}=23)\end{array}$ & $\begin{array}{c}26 \text { proc. } \\
(\mathrm{n}=6)\end{array}$ & $\begin{array}{c}74 \text { proc. } \\
(\mathrm{n}=17)\end{array}$ \\
\hline 2. & $\begin{array}{l}\text { Staphylococcus } \\
\text { aureus }\end{array}$ & $\begin{array}{c}100 \text { proc. } \\
(\mathrm{n}=23)\end{array}$ & $\begin{array}{c}26 \text { proc. } \\
(\mathrm{n}=6)\end{array}$ & $\begin{array}{c}74 \text { proc. } \\
(\mathrm{n}=17)\end{array}$ \\
\hline
\end{tabular}

diagnostinio aparato duomenimis. Analizuojant duomenis apie klientų odos būklę po atliktų procedūrų nustatyta, kad daugiau nei ketvirtadaliu padidejjo skaičius klientų, kuriems buvo diagnozuotas normalus hidratacijos (drègmès) lygis ir trečdaliu sumažèjo klientų su žemos hidratacijos (drégmès) lygiu, lyginant su "Soft plius" diagnostinio aparato duomenimis, po pirmosios ir trečiosios procedūros. Panašios tendencijos stebimos ir vertinant klientu odos ph. Nustatyta, kad 1,5 karto padidèjo skaičius klientų, kuriems buvo diagnozuotas normalus odos ph, lyginant "Soft plius" diagnostinio aparato duomenimis po pirmosios ir trečiosios procedūros, atitinkamai 38,5 proc. bei 55,8 proc. (2 paveikslas).

Atsižvelgiant ì trečiame paveiksle pateiktus duomenis, nustatyti klientų veido odos porų diametro pokyčiai: daugiau nei du kartus sumažèjo klientų skaičius, kuriems diagnozuotos labai atviros odos poros, lyginant su "Soft plius" diagnostinio aparato duomenimis, po pirmosios ir trečiosios procedūros atitinkamai 80,8 proc. bei 36,5 proc. ( 3 paveikslas).

Iš ketvirtame paveiksle pateiktų duomenų matome, kad kosmetologo vizualinès diagnostikos metu stebimi odos papulių skaičiaus pokyčiai: po antrosios atliktos procedūros naudojant veido odos šveitiklį su vaisinèmis alfa hidroksi rūgštimis lyginant su pirmaja procedūra 1,5 karto sumažèjo klientų skaičius, kuriems diagnozuotos 10 ir daugiau papulių regimajame lauke, atitinkamai 7,5 proc. bei 11,5 proc., o po trečiosios procedūros tokių klientų nebuvo visai (4 paveikslas).

Panašios tendencijos stebimos ir analizuojant penktame paveiksle pateiktus duomenis, kosmetologo vizualinès diagnostikos metu stebimi odos pustuliu skaičiaus pokyčiai: po trečiosios atliktos procedūros naudojant veido odos šveitiklị su vaisinėmis alfa hidroksi rūgštimis neliko klientụ, kuriems būtų diagnozuotos 7 ir daugiau pustulių regimajame lauke. 2 kartus sumažèjo klientu skaičius, kuriems diagnozuotos 4-6 pustulès regimajame lauke lyginant trečiosios ir pirmosios procedūros duomenis, atitinkamai 36,5 proc. bei 15,4 proc. taip pat po trečios atliktos procedūros lyginant su pirmaja procedūra 5 kartus padidèjo klientų skaičius, kuriems nebuvo diagnozuotos pustulès regimajame lauke (5 paveikslas).

Akne mikrobiologinio tyrimo duomenys rodo, kad 26 proc. tiriamujjų (4 lentelè) iš pūlių išaugo Propionibacte- 
rium acnes ir Staphylococcus aureus. Tirtos bakerijos neišaugo 74 proc. tiriamujų

\section{Rezultatų aptarimas}

1896 metais buvo nustatyta, kad bakterijos, esančios aknès pažeistoje odoje, yra tiesioginiai aknès sukèlèjai. Vèlesni tyrimai patvirtino šių bakterijų svarbą aknès patogenezèje [11]. Propionibacterium acnes (anksčiau Corynebacterium parvum) yra odos mikrobiota. Tai gramteigiamosios lazdelès, aerotoleranciniai anaerobai, nesudarantys sporu [12]. Be Propionibacterium acnes čia yra ir mielių Malassezia, stafilokokų ir mikrokokų [13]. Propionibacterium acnes yra žmogaus odos komensalinė mikroflora, susijusi su spuogų patogeneze [14]. Aknè yra viena iš labiausiai paplitusių odos ligų, nuo kurių kenčia daugiau nei 45 milijonų žmonių Jungtinèse Amerikos Valstijose. Manoma, kad beveik 20 proc. visų apsilankiusių pacientų pas dermatologą kreipiasi dèl spuogų. Aknė dažniausiai pasireiškia paaugliams, tačiau ja gali sirgti ir suaugusieji - tai dažnai susiję su hormonų svyravimų menstruacinio ciklo ar néštumo metu.

Shehadeh ir Kligman [15] ištyrè iš 71 komedono (45 atvirų ir 26 uždarų) paimtą tiriamają medžiagą: Propionibacterium acnes ir Staphylococcus aureus išaugo iš 96 proc. atvirų ir 92 proc. uždarų komedonų. Ištyrus 104 aknès atvejus, Propionibacterium acnes bei Staphylococcus aureus išaugo 79 proc. ir 61 proc. Daugelio autorių duomenys rodo, kad dažniausiai aknès pūlinukuose yra Propionibacterium acnes ir Staphylococcus aureus bakterijos - 73 proc. ir 60 proc. [3].

Staphyococcus aureus yra žmogaus mikrobiota - iki 40-60 proc. žmonių šias bakterijas turi šnervèse. Šie stafilakokai gali kolonizuoti odą bei gleivines, sukeldami odos bei gleivinių pūlinę infekciją [16]. Visuomenejje cirkuliuojančios Staphyococcus aureus ir jų meticilinui atsparios padermès iš visuomenès plinta ligoninèse, sukeldamos pūlinius uždegiminius procesus. Antimikrobinèms medžiagoms

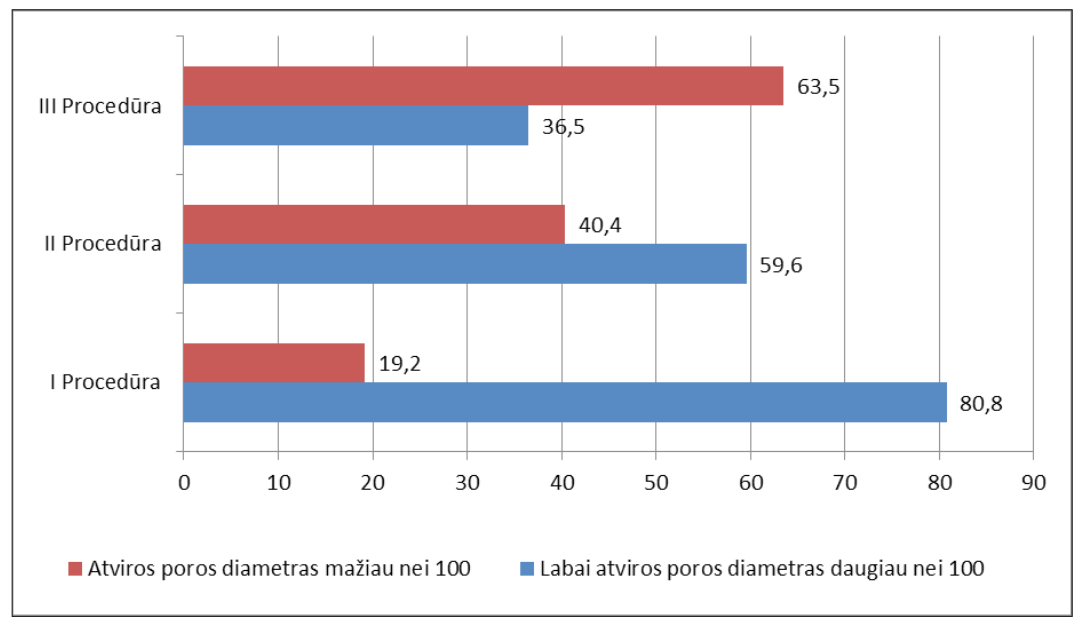

3 pav. Klientų veido odos porų diametro pokyčiai (proc.) Soft plius diagnostinio aparato duomenimis

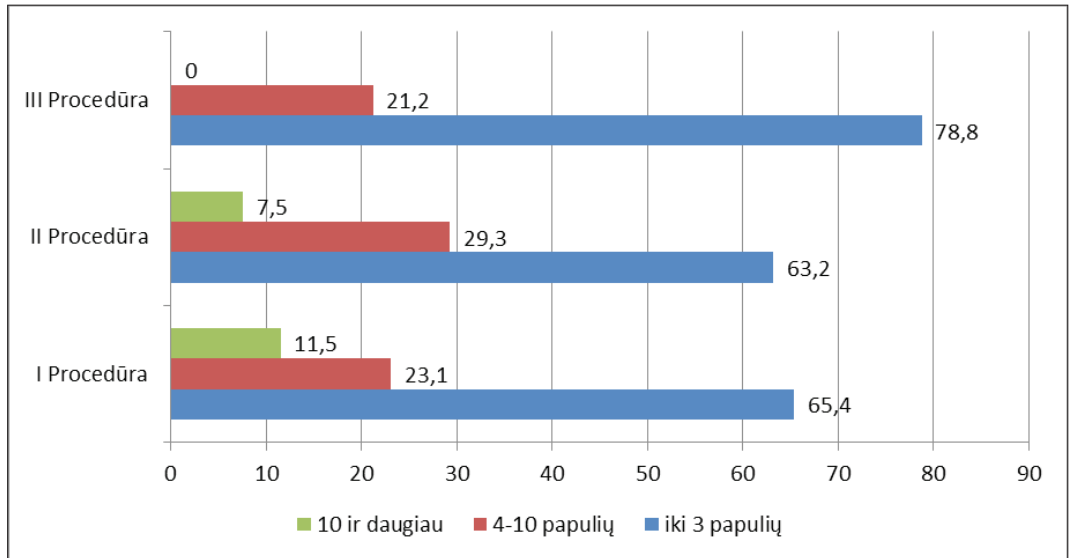

4 pav. Klientų veido odos papulių skaičiaus pokyčiai (proc.) regimajame lauke kosmetologo vizualinès diagnostikos metu

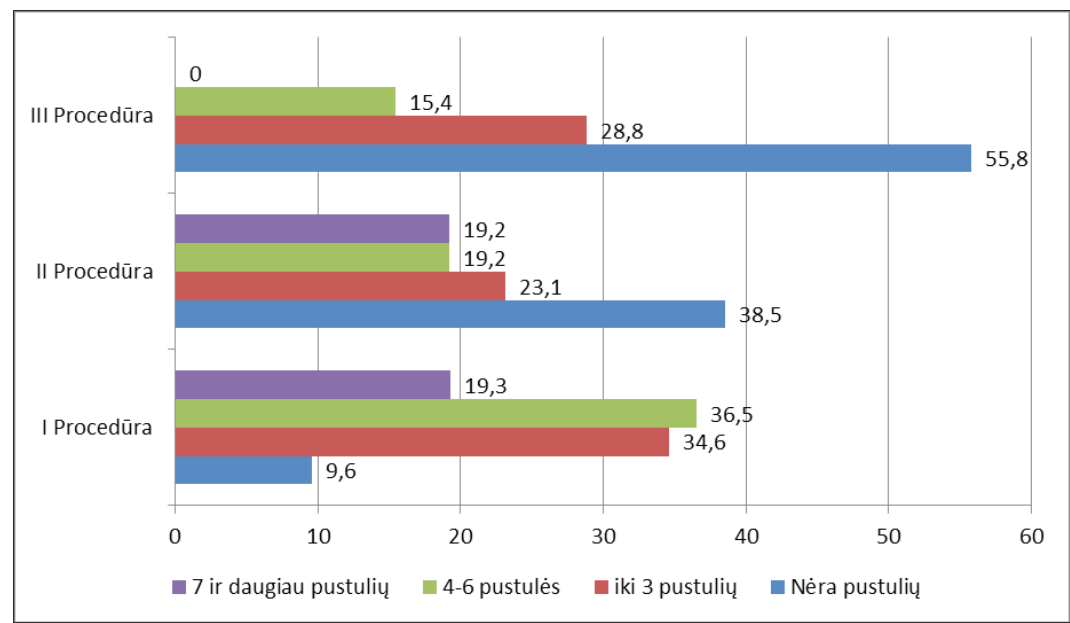

5 pav. Klientų veido odos pustulių skaičiaus pokyčiai (proc.) regimajame lauke kosmetologo vizualinès diagnostikos metu 
atsparios Staphyococcus aureus padermès, patekusios ị stacionarus ir juose išplisdamos, dažnai yra hospitalinių infekcijų protrūkių priežastis [17].

Mokslinių tyrimų duomenimis, jaunatvinių spuogų susidarymą lemia keletas veiksnių: padidejusi riebalinių liaukų veikla, folikulo hiperkeratinizacija bakterijų Propionibacterium acnes kolonizacija ir atsirandanti uždegiminè reakcija. Jie pasižymi šiais požymiais: neuždegiminiais odos bèrimo elementais (atvirais ir uždarais komedonais), uždegiminiais bèrimo elementais (papulès, pustulès, mazgeliai, cistos). Jaunatvinių spuogų atsiradimui įtakos turi: endokrininiai ir genetiniai faktoriai, sezono pokyčiai, mechaninè trauma, cheminès medžiagos, medikamentai, maistas $[18,19]$. Taip pat aknès atsiradimui ir eigai ịtakos turi paveldimumas, lemiantis sunkios eigos spuogus. Specifiniai aknès paveldèjimo mechanizmai nèra žinomi, manoma, kad polinkị ị spuogus lemia keletas genų, pirmiausia - koduojantys citochromą P450-1A1 ir steroidą-21 - hidroksilazę.

Aknès paplitimas, sunkumas, klinikinè simptomatika ir pasekmès priklauso nuo genetinès predispozicijos, hormonų apykaitos sutrikimų, streso, žalingų ipročių, mitybos ir aplinkos veiksnių (European Dermatology Forum, 2011) $[2,20]$. Aknès keliamų problemų sprendimai gali būti ịvairūs, todèl labai svarbu šiuo atveju gydytojo dermatologo, kosmetologo nuomonè bei aknès diagnostika, kurios pagalba parenkamas aknès gydymas priklausomai nuo odos bẻrimų elementų skaičiaus, komedonų tipo - uždari ar atviri, jų lokalizacijos, odos riebumo, porų dydžio, odos $\mathrm{pH}$, melanino, drégmés kiekių, elastingumo [9,21-23].

Aknè - tai liga, kuri žmogų veikia ne tik fiziškai, bet ir psichologiškai. Streso padidèjimas turi ịtakos aknès suaktyvejjimui, o aknès suaktyvejjimas, naujų spuogų atsiradimas sukelia psichologinių problemų. Tai pasireiškia mažesniu pasitikèjimu savimi, sukelia psichologini diskomfortą, trukdo bendrauti su aplinkiniais, gali sukelti depresiją [24,25]. Epidemiologinių tyrimų duomenimis, asmenims, sergantiems sunkesne aknès forma, sunkiau aktyviai dalyvauti akademinèjè veikloje, tarp tokių asmenų dažnai būna didesni nedarbo rodikliai, palyginus su tais, kurie neserga akne. Sergančiųų akne socialinių, psichologinių ir emocinių problemų lygmenys buvo palyginti su asmenų, kurie serga kitomis chroniškomis ligomis, taip pat galinčiomis sukelti diskomfortą, tokiomis kaip astma, epilepsija, diabetas, juosmens skausmai ir artritas. Sergančiųu akne asmenų depresijos lygis buvo didesnis nei sergančiųų atopiniu dermatitu, žvyneline, paveikiančia mažiau kaip 30 proc. viso kūno paviršiaus ploto $[26,27]$.

Pagrindinis lengvos formos aknès gydymo būdas - kasdienis odos valymo priemonių (želè, prausiklių, specialaus muilo, losjono) naudojimas namuose, esant sunkesnèms formoms dažnai neapsieinama be kosmetinių procedūrų kosmetikos kabinete. Moksliniais tyrimais irodyta, cheminiai šveitikliai padeda klientams spręsti aknès keliamas problemas. Jų panaudojimas yra gana platus ir veiksmingas, naudojant vienus, atliekant kombinacijas, taip pat pasižymi ịvairiu poveikiu jaunatviniams spuogams: padeda sumažinti jaunatvinių spuogų bèrimo elementus [28], atsluoksniuoja viršutini odos sluoksni, atveria užsikimšusias odos poras, sumažina hiperpigmentaciją, atsiradusią po uždegiminių bẻrimo elementų [29].

Išnagrinejjus cheminių šveitiklių veikimo mechanizmą ir poveiki odai, galima teigti, kad jie mažina hiperkeratinizaciją, šviesina antrinę pigmentaciją, daro ịtaką regeneracijos stimuliacijai, išlaisvindami tarpląstelines ląstelių jungtis, taip sumažindami jaunatvinių spuogų atsiradimo priežastis ir odos bėrimo elementų skaičių [30,31].

Paviršiniai cheminiai šveitikliai yra saugūs naudoti visiems odos tipams, veikia tik epidermi, todèl tinkami naudoti tik paviršinių defektų šalinimui - jaunatviniams spuogams, geriausiam rezultatui yra rekomenduojama keletas paviršinių cheminių šveitiklių procedūrų. Paviršinių cheminių šveitiklių sudetyje yra naudojamos cheminès medžiagos, kurios ardo epidermi, joms priklauso alfa hidroksi rūgštys. Šios rūgštys natūraliai randamos cukranendrèse, surūgusiame piene, ịvairiuose vaisiuose. Jų veikimo mechanizmas pagrịstas korneocitų sukibimo mažinimu po grūdètuoju sluoksniu, desmosomų skaičiaus mažinimu, kas sukelia odos atsluoksniavimą [32]. Glikolio rūgštis yra alfa hidroksi rūgštis, sudaryta iš dviejų anglies atomų ir pasižymi itin maža molekuline mase, tirpsta alkoholyje, išgaunama iš vaisių ir pieno cukraus. Glikolio rūgštis pasižymi keratolitinėmis, priešuždegiminèmis, antioksidacinèmis, stimuliuojančiomis bazalini sluoksnị ir fibroblastus savybėmis. Veikimo mechanizmas paremtas korneocitu tarpusavio ryšių sumažinimu jų gamybos fazejje: padidina vandens kiekị raginiame sluoksnyje, dèl šios priežasties geriau pasišalina išorinio raginio sluoksnio ląstelès, pagerẻja veikliųų medžiagų ịsiskverbimas, išsklaido bazalinio sluoksnio melaniną, didina epidermio ir dermos hialurono rūgšties ir kolageno geno ekspresiją, pakilus interleukino sekrecijai [33-35].

Tyrimo duomenimis, klientams atliktos trys odos šveitimo procedūros su vaisinèmis alfa hidroksi rūgštimis taip pat turèjo teigiamą efektą odos būklei. Analizuojant duomenis apie klientų odos būklę po atliktų procedūrų nustatyta, kad daugiau nei ketvirtadaliu padidejo skaičius klientų, kuriems buvo diagnozuotas normalus hidratacijos (drègmès) lygis ir trečdaliu sumažèjo klientų su žemos hidratacijos (drègmès) lygiu bei 1,5 karto padidejo skaičius klientų, 
kuriems buvo diagnozuotas normalus odos ph, lyginant po pirmosios ir trečiosios procedūros. Nustatyti klientų veido odos porų diametro pokyčiai: daugiau nei du kartus sumažèjo klientų skaičius, kuriems diagnozuotos labai atviros odos poros, lyginant po pirmosios ir trečiosios procedūros. Kosmetologo vizualinès diagnostikos metu nustatytas odos papulių ir pustulių skaičiaus sumažèjimas.

\section{Išvados}

1. Klientams atliktos trys odos šveitimo procedūros su vaisinèmis alfa hidroksi rūgštimis turejo teigiamą efektą odos būklei: po trečiosios procedūros didesniam skaičiui klientų buvo diagnozuotas normalus odos ph bei hidratacijos (drègmès) lygis, sumažejo labai atvirų porų diametras, vizualiai vertinant sumažèjo papulių ir pustulių skaičius.

2. Akné daugumai respondentų sukelia psichologinę įtampą, sunkumų laisvalaikiulsportuojant, trukdo bendrauti su mylimaisiais. Jie jaučiasi pažeidžiami ir prasčiau vertina sveikatą. Klientai, besiskundžiantys akne ir aktyviai spendžiantys savo problemas gydytojo, kosmetologo konsultacijomis, aparatinèmis sprocedūromis bei specialiomis kosmetinėmis priemonès, savo sveikatą vertina geriau.

3. Propionibacterium acnes ir Staphylococcus aureus išskirti 26 proc. $(n=6)$ tiriamujų.

\section{Literatūra}

1. Rzany B, Kahl C. Epidemiology of acne vulgaris. Journal der Deutschen Dermatologischen, 2006; 4:8 - 9 .

2. Krakowski AC, Stendardo S, Eichenfield LF. Practical considerations in acne treatment and the clinical impact of topical combination therapy. Pediatr Dermatol. 2008 Jun;25

3. Karčiauskienė J., Valiukevičienė S. Paprastujų spuogų (aknės) paplitimas ir rizikos veiksniai. Lietuvos bendrosios praktikos gydytojas, tomas XIV, 2010; 6:448 - 453 .

4. Barnes LE, Levender MM, Fleischer AB Jr, Feldman SR. Quality of life measures for acne patients. Dermatol Clin. 2012 Apr; 30(2):293-300.

5. Matsuoka Y, Yoneda K, Sadahira C, Katsuura J, Moriue T, Kubota Y. Effects of skin care and makeup under instructions from dermatologists on the quality of life of female patients with acne vulgaris. J Dermatol. 2006 Nov;33(11):745-52.

6. Kim RH, Armstrong AW. Current state of acne treatment: highlighting lasers, photodynamic therapy, and chemical peels. Dermatol Online J. 2011 Mar 15;17(3):2.

7. Ilknur T, Demirtaşoğlu M, Biçak MU, Ozkan S. Glycolic acid peels versus amino fruit acid peels for acne. J Cosmet Laser Ther. 2010 Oct;12(5):242-5.

8. Kessler E, Flanagan K, Chia C, Rogers C, Glaser DA. Comparison of alpha- and beta-hydroxy acid chemical peels in the treatment of mild to moderately severe facial acne vulgaris. Dermatol Surg. 2008 Jan; 34(1):45-50.
9. Eichenfield LF, Krakowski AC, Piggott C, Del Rosso J, Baldwin H, Friedlander SF, Levy M, Lucky A, Mancini AJ, Orlow SJ, Yan AC, Vaux KK, Webster G, Zaenglein AL, Thiboutot DM; American Acne and Rosacea Society.Pediatrics. Evidencebased recommendations for the diagnosis and treatment of pediatric acne.2013 May; 131.

10. Lovečkova Y, Havlikova I. A microbiological approach to acne vulgaris.// Biomedical Papers, 2002; 146 (2):29-31.

11. Dessinioti C, Katsambas AD. The role of Propionibacterium acnes in acne pathogenesis: facts and controversies.// Clinics in Dermatology, 2010; 28:2 - 3.

12. Bojar RA, Holland KT. Acne and Propionibacterium Acnes.// Clinics in Dermatology, 2004; 22:375-379.

13. Shaheen B, Gonzalez M. A microbial aetiology of acne: what is the evidence?.// British Journal of Dermatology, 2011; 165:474, $479-481$.

14. Kirschbaum JO, Kligman AM. The pathogenic role of Corynebacterium acnes in acne vulgaris. Archives of Dermatology. 1963;88:832-833.

15. Shehadeh N, Kligman AM. The bacteriology of acne.// Archives of Dermatology 1963; 88:31.

16. Karchmer AW. Nosocomial bloodstream infections: organisms, risk factors, and implications. Clin Infect Dis. 2000;31 Suppl 4:S139-43.

17. Herwaldt LA. Control of methicillin-resistant Staphylococcus aureus in the hospital setting. Am J Med . 1999;106:11S-8S; discussion 48S-52S.

18. Hywel CW, Dellavalle RP, Garner S. Acne vulgaris. The Lancet, 379,2011, p. $361-363$.

19. Hogewoning AA, Koelemij I, Amoah AS, Bouwes Bavinck JN, Aryeetey Y, Hartgers F, et al. Prevalence and risk factors of inflammatory acne vulgaris in rural and urbal Ghanaian schoolchildren, British Journal of Dermatology 2009; 161(2):7.

20. Guidelines for the treatment of acne: European Dermatology Forum, 2011.

21. Gollnick H. Current concepts of the pathogenesis of acne: implications for drug treatment University Clinic for Dermatology and Venerology 2003; 15:1579-1596.

22. Jerry KL Tan. Current Measures for the Evaluation of Acne Severity Expert Reviews Dermatology 2008 march; 5.

23. Titus S., Hodge J. Diagnosis and treatment of acne//Am Fam Physician 2012 october, nr.8.

24. Aktan S, Ozmen E, Sanli B. Anxiety, depression, and nature of acne vulgaris in adolescents.// International Journal of Dermatology 2000; 39:354.

25. Bhate K, Williams HC. Epidemiology of acne vulgaris. British Journal of Dermatology, 2012; 168:476, 478, 480 - 481.

26. Uhlenhake E, Yentzer BA, Feldman SR. Acne vulgaris and depression: a retrospective examination.// Journal of Cosmetic Dermatology, 2010; 9:61-65.

27. Dréno B. Assessing quality of life in patients with acne vulgaris: implications for treatment.Am J Clin Dermatol. 2006; 7(2):99106. 
28. Jusitus J. Ablative, nonablative rejuvenation fractional, adjunctiveoptions expanding//Dermatology Times, 2008; 68.

29. Cheryl G. Survey: Chemical peels remain mainstay in dermatologie surgery armamentarium//Dermatology Times 2008 January; 72 .

30. Khunger N, IADVL Task Force. Standard guidelines of care for chemical peels. Indian J Dermatol Venereol Leprol. 2008 Jan; 74.

31. Rendon Marta I, Berson Diane S, Cohen Joel L, Roberts Wendy E, Starker I, Wang B. Evidence and Considerations in the Application of Chemical Peels in Skin Disorders and Aesthetic Resurfacing//The Journal of Clinical and Aesthetic Dermatology 2010; 3: $32-43$.

32. Savage Laura J, Lanton Alison M. Treating Acne Vulgaris: Systemic, Local and Combination Therapy//Expert Review of Clinical Pharmacology, 2010; 4:563 -580.

33. Tosti A, Grimes Pearl E, De Padova Maria P. Color Atlas of Chemical Peels. - Springer, 2012.

34. Ilknur T, Demirtaşoğlu M, Biçak MU, Ozkan S. Glycolic acid peels versus amino fruit acid peels for acne. J Cosmet Laser Ther. 2010 Oct;12(5):242-5.

35. Yin R, Hao F, Deng J, Yang XC. and Yan H. Investigation of optimal aminolaevulinic acid concentration applied in topical aminolaevulinic acid-photodynamic therapy for treatment of moderate to severe acne: a pilot study in Chinese subjects// Journal Compilation 2010 British Association of Dermatologists, British Journal of Dermatology 2010; 163:1064-1071.

CORRELATION OF STUDENTS`ACNE DIAGNOSTICS, COSMETIC PROCEDURES AND MEASURES AND SUBJECTIVE EVALUATION OF HEALTH

J. Kirvaitienė, Ž. Maželienė, V. Vaikšnorienė, Ž. Mickienė, A. Vaičiulevičienė

Key words: Propionibacterium acne, staphylococcus aureus, acne vulgaris, chemical peels.
Summary

Acne is a chronic condition having an effect on people's life, causing psychological problems, damaging their life quality. There are a lot of ways to solve the problem starting with cosmetic means and finishing with laser. Chemical scouring means is one of ways to improve the situation.

Objective - to evaluate the correlations of student's acne diagnostics, cosmetics procedures and measures and subjective evaluation of health. The study has stated that patients who have no blotch, greasy skin problems better evaluate their health.

Acne causes psychological tension, difficulties doing sports, communicating with lovers. They feel much worse than those who do not face acne problems $((\mathrm{p}<0,05)$. Those who try to solve the problem consulting doctors take cosmetic consultations or other special cosmetic means take the problem easier.

Skin scouring procedures with fruit alpha hydroxy acids had positive effect on the skin. Analysing the data of clients skin condition after taking procedures it has been stated that the number of clients with normal hydration level increased more than $1 / 4$ and the number of clients with low level hydration decreased $1 / 3$ and the number of clients with normal skin ph increased 1,5 times compared after the first and third procedures. It has been determined clients face skin pore diameter changes - the number of clients with very open skin pores decreased more than twice if compared after the first and third procedures. Cosmetological visual diagnostics are observed skin papules and pustules lower number.

Correspondece to: jolita.kirvaitiene@1smnuni.1t

Gauta 2013-07-02 